\title{
The Authenticity of the Former Mining Landscapes of Kinta Valley, Malaysia
}

\author{
Suriati Ahmad ${ }^{1}$, David Jones ${ }^{2}$ \\ ${ }^{1} \mathrm{PhD}$ student, School of Architecture \& Built Environment, Deakin University, Australia \\ 2 Director - Planning \& Landscape Architecture Programs, \\ School of Architecture \& Built Environment, Deakin University, Victoria, Australia.
}

suriati@deakin.edu.au

\begin{abstract}
Kinta Valley in Perak State is one of the richest valley arising from 18th century tin mining production in Malaysia. The physical evidence of this production that surrounds Kinta offers a cultural landscape narrative about this 'tin rush' era that occurred from 1884 to 1895 . This paper investigates the heritage significance of Kinta Valley former mining landscape through the lens of cultural landscape theory and practice. Through a detailed case study, documentary research and site observation have been applied as qualitative methods for data collection to unravel and quantify the heritage values of the Kinta Valley former mining landscape.
\end{abstract}

Keywords: Culture landscape; vernacular landscape; tin mining; Kinta Valley

eISSN 2514-751X C 2018. The Authors. Published for AMER ABRA CE-Bs by e-International Publishing House, Ltd., UK. This is an open-access article under the CC BY-NC-ND license (http://creativecommons.org/licenses/bync-nd/4.0/). Peer-review under responsibility of AMER (Association of Malaysian Environment-Behaviour Researchers), ABRA (Association of Behavioural Researchers on Asians) and CE-Bs (Centre for EnvironmentBehaviour Studies), Faculty of Architecture, Planning \& Surveying, Universiti Teknologi MARA, Malaysia DOI: https://doi.org/10.21834/aje-bs.v3i10.321 


\subsection{Introduction}

In Malaysia, although tin is not the only metallic mineral that has been historically exploited, tin is one of the major minerals that contributed to Malaysia's economy since the early 18th century. Tin deposits can only be found in Peninsular Malaysia with Perak State as the leading venue for tin production. Lim (cited in Osman, 2013) estimates that the total hectarage of mining land in Peninsular Malaysia in 1970 was 158,968 ha whereby Perak State dominated with 71,394 ha followed by Terengganu (31,754 ha) and Selangor $(25,570$ ha) states. Osman \& Ishak (2012) conclude that the former mining land of Perak covers 3.9\% of the State's land with Kinta District dominating with 47,614 ha (58.2\%) followed by Batang Padang 21,064 ha (25.8\%), Perak Tengah 5,095 ha (6.2\%), Larut Matang 4,610 ha (5.6\%), Kuala Kangsar 1,581 ha (1.9\%), Hulu Perak 982 ha (1.2\%), Manjung 661 ha $(0.8 \%)$, and Hilir Perak 143 ha $(0.2 \%)$ districts. Therefore, former tin mining landscapes in Perak are of state and national eminence, and have led to the growth of Perak's economy and the expansion of its social and culture diversity that characterises Malaysia today. While all are of importance, Kinta Valley (embracing Kinta District and Kampar District) has been selected as this case study to investigate its cultural landscape significance and thereupon quantifying its heritage values that are embedded within this landscape.

\subsection{Literature Review}

\section{(i)The concept of cultural landscape}

Humans and nature have a long history of interrelationships and dependencies. Thus remnants of the past lie within landscape layers generating a mosaic in the landscape (Lennon, 1997). Taylor (2009, p. 13) however describes cultures as "the shaping force" whereby landscape is interpreted as the creation of a cultural expression through human ideology. UNESCO, through its Operational Guidelines for the Implementation of the World Heritage Convention (2012, p. 14), defines 'cultural landscapes' as the "combined works of nature and of man"' demonstrating human interrelationships and interventions towards its environment. Further, within the UNESCO Operational Guidelines (2012), cultural landscape is classified into three main categories consisting of 'designed landscape', 'organically evolved landscape' (or 'vernacular landscape'), and 'associative cultural landscape'. In dealing with mining or industrial landscapes, these landscapes are classified as 'vernacular landscape' as it has evolved organically through human activities that have impacted upon land use and spatial organization of specific or collective areas. As a consequence, industrial landscapes offer rich evidence of heritage values. UNESCO, through its World Heritage List, has acknowledged historic mining landscapes as being part of their cultural landscape category although mining activities are often seen as destroying land (e.g. ground contamination, pollution, etc.), as many environmentalists critique these lands as "'a lessthan-sustainable involvement"' (American Society of Landscape Architects, n.d).

However the values embedded within these landscape are able to portray the "special relationship between man and nature'", and therefore land transformation is a product of this 
correlation (American Society of Landscape Architects, n.d). The evidence of heritage mining landscapes with outstanding universal values are acknowledged by the UNESCO World Heritage Centre as involving 4 properties: Blaenavon industrial landscape, UK; Cornwall and West Devon mining landscape, UK; Nord-Pas de Calais Mining Basin, France; and Iwami Ginzan Silver Mine and its Cultural Landscape, Japan. Iwami Ginzan is the first property in Asia Pacific to be nominated for its heritage mining landscape significance and therefore demonstrates a gap in knowledge and practice that exists within the context of South East Asia especially highlighting the merit of this research.

\section{(ii)The characteristics of mining heritage sites, areas and landscapes}

Historic mining sites consist of physical evidence and evidence of its processing activity including mine workings, machinery, quarries, shafts, bridges, roads/tracks, surface dumps, slag heaps, surface structures and settlement patterns (Ballinger, 2012; Drew, 2012). Detail of heritage mining components and their associated features, as described by Pearson and McGowan (2000, pp. 17-18), include:

[ Mine working and operational areas from all periods of a mine's operation including sluicing, open cuts, pits, costeans, shafts, adits, headframes, winders, engines, boilers, equipment and machineries, mullock and tailings heaps, shower blocks, administration buildings, etc.;

[ Primary processing batteries and mills (crushers, roasters, chimneys, flues, etc.) and secondary processing plant, such as smelters and refineries;

[ Miner's living sites including-miners' housing, villages and towns (huts, barracks, tent sites, village sites and buildings, cemeteries, etc.);

[ Transportation system including-roads and tramways associated with the movement of mining supplies and minerals;

Infrastructure to support the mine, such as water supply (dams, races, pipelines) timber mills, smithies and foundries, brickworks, hydro-electric plant, etc.;

\ Aspects of settlement stimulated by mining such as-agriculture and market gardening, closer settlement, port development, railway extension, etc.; and

口 Landscape modification due to mining such as deforestation, pollution-induced barren areas, silted dams, open cuts, embankments and mounds, tailings dumps, dredged streams, modified vegetation, etc.

\section{(iii)International Charters concerning on Industrial Heritage}

The Nizhny Tagil Charter for Industrial Heritage, that was drafted by the International Committee for the Conservation of Industrial Heritage $(\mathrm{TICClH})$ in 2003, asserts that "buildings and structures built for industrial activities, the processes and tools used within them and the towns and landscapes in which they are located, along with their tangible and intangible manifestations, are of fundamental importance" (TICCIH, 2003). This Charter highlights the process of identifying values of industrial heritage that involves identification, survey, recording and assessment to formulate heritage significance. The Nizhny Tagil Charter was adopted by $\mathrm{TICCIH}$ to form the Joint ICOMOS-TICCIH principles for the 
conservation of industrial heritage sites, structures, areas and landscapes in 2011 and these principles have been recognized internationally by the UNESCO.

\section{(iv)Legal framework related to heritage conservation in Malaysia}

In Malaysia, although there is legislation that is gazetted for heritage conservation (e.g. Act 645-National Heritage Act 2005; Act 172-Town and Country Planning Act 1976), none of these Acts address the importance of industrial heritage or specifically embrace mining heritage conservation. Other than Acts, the Malaysian National Landscape Department has taken initiative in establishing the National Landscape Policy, and within the content of this policy- places with cultural landscape significance (stressing visual and cultural importance) will be identified and restored. But the document- only identifies agricultural landscapes, and not mining landscapes, for the promotion as agro-tourism venues. Gaps in knowledge clearly exist as it relates to industrial landscape and heritage conservation in Malaysia.

\subsection{Methodology}

Because this paper used a single case study evaluation, a qualitative research approach was adapted to generate multiple research findings. The methods used included documentary research (including site historical research, archival records and geospatial data) and site observations. In this context, Pearson and McGowan (2000, 2009), whom adopted the Australian Burra Charter methodological process, recommended the gathering of information to understand the history of the place as an essential step to understand the evolution, timeline(s) and technology(ies) that may have significantly impacted upon this landscape. In addition, site inventory and observation was also conducted to validate the documentary research as well as to map the extant condition of the landscape and its features. For the purpose of this paper, two assessment tools have been selected; the criteria for Malaysian National Inscription (as specified in the National Heritage Act 2005--Section 67: Declaration of National Heritage) and ranking of significance criteria applied by the Heritage Branch of the New South Wales (NSW) Department of Planning. Within the context of the National Heritage Act 2005, no cultural landscape category exists, but the heritage criteria embodied in this Act is practical and sufficient to measure heritage values embedded within the Kinta Valley former mining landscape. Likewise, the grading system used for ranking of significance values, as applied by the NSW Department of Planning focuses upon individual items or features of heritage importance has also been applied in this paper. The results from this grading will further be used to qualify the heritage values using the National Heritage criteria as the main tool for justifying recognition of historic mining landscape.

\subsection{Results and Discussions}

\subsection{Qualifying the cultural landscape significance}


Based upon site survey and documentary research, Gopeng and Tanjung Tualang both appear to have very outstanding features and values which demonstrate a high degree of integrity associated with the heritage mining landscape in Kinta, including: a mining dam, located at the upper stream of Kampar river, built specifically to cater for mining production in Gopeng and its surrounding areas in the early $20^{\text {th }}$ century (Figure 1); in channelling water from this Dam, 2 pipelines were installed $13.6 \mathrm{~km}$ long by the Gopeng Tin Mining Co. Ltd in 1908 under engineer F.D Osborne to supply water to the mining areas in Gopeng (Figure 2). This mining dam and pipeline has been abandoned due to the cessation of mining operations in 1992 which forced mining operators to cease their mining operations due to the international tin market collapse in 1985. In relation to the mining closure, the pipeline and its structure were no longer insured and maintained, and posed a danger to road users and therefore after 100 years of use, this pipeline and its supporting structure were finally dismantled. Realizing its heritage significance, the contractor "generously donate[d] two pipelines with 30 meter long to Perak State Government" (Kampar District Council, 2011) [sic].

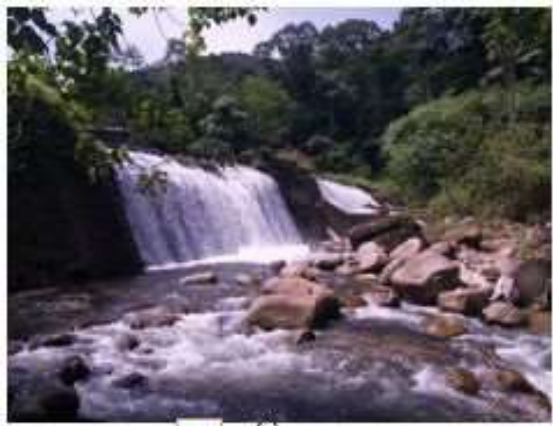

(d)

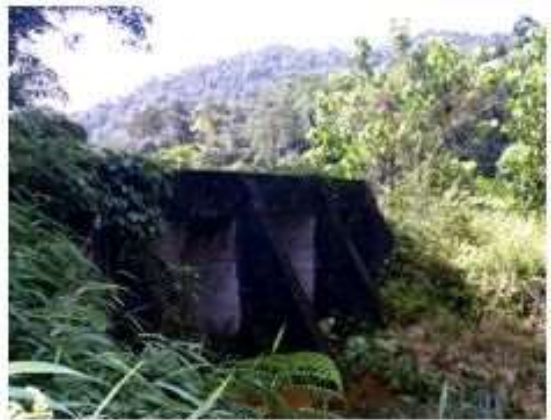

(b)

Fig. 1. (a) Mining dam which is located at the upper stream of Kampar river; (b) The pipeline supporting structure which are no longer in used and currently abandoned.

Source: author 2013

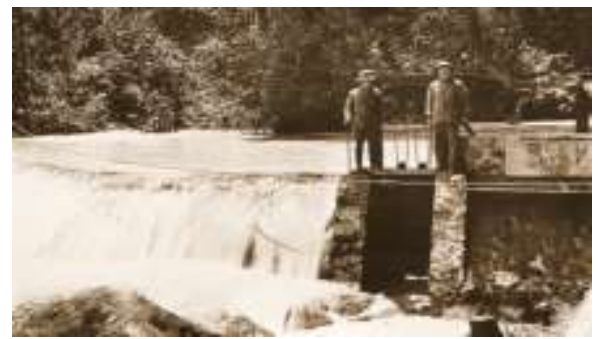

(a)

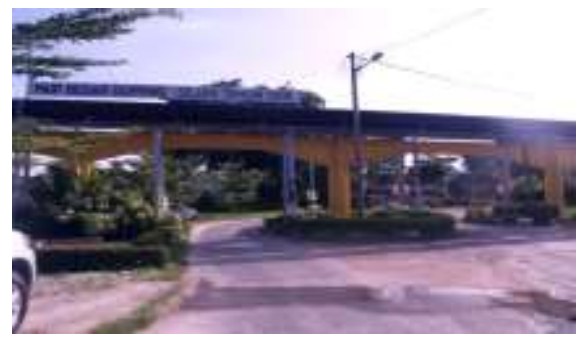

(b)

Fig. 2. (a) Ulu Geroh Dam, Gopeng; (b) Gopeng giant pipes

Source: (a) courtesy image by Kampar Tin Mining (Gravel Pump) Museum (b) author 2013 
Under in international terminology on archaeology, the Tanjung Tualang Tin Dredge that was built in 1938 in England by F.W. Payne and that operated for 44 years until August 1982, can be classified as an industrial archaeology relic (The Malaysian Chamber of Mines, n.a). After nearly 75 years this dredge still survives and the Malaysia Mining Corporation Berhad (MMC) has donated it to the Perak State Government as a heritage legacy for future generations as demonstrating a part of Kinta Valley's former mining glory in the late $19^{\text {th }}$ and $20^{\text {th }}$ centuries. This dredge is currently maintained by Osborne \& Chappel Sdn. Bhd. (OCSB); the same subsidiary company that installed the Gopeng giant pipes (Figure 3).

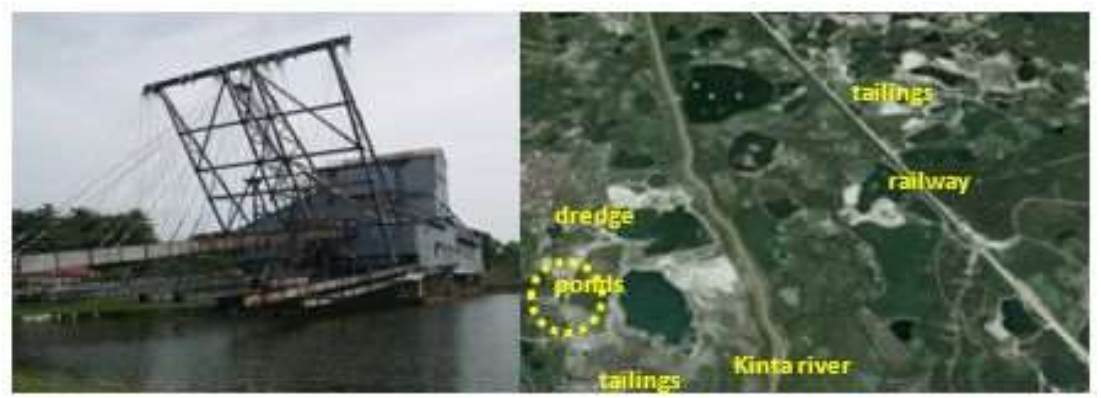

(a)

(b)

Fig. 3. (a) Tanjung Tualang Tin Dredge, Kinta; (b) Google Earth; The location of Tanjung Tualang Tin Dredge

Source: (a) author 2013, (b) Google Earth

Geologically Perak is known for its alluvial mining deposits which can be easily extracted using the 'power of water'. This method, once used in Kinta District, focuses on panning, gravel pumping, hydraullicing and dredging that created the mining landscape that can be observed in Kinta Valley today. These methods do not involve the primary processing batteries and mills. There are 4 companies today registered for tin smelting in Perak and they are located in Ipoh, Mambang Di Awan and Kampung Kepayang thereby continuing the tin mining process heritage and adding to the significance values of the historic mining landscape in Kinta Valley (www.Malaysia.com, 2013). The amang retreatment plant involves an extraction process of by-product minerals from tin mining production and in Kinta Valley, these amang factories still exist and can be found in Kampar, Papan, Pusing and Siputeh and thereby additionally continuing this mining heritage.

Miners living sites, that include villages and towns, still exist in most of the study area, and these include the main roads that were built in the late $19^{\text {th }}$ century, for easy access of transportation and the movement of mining supplies and minerals connecting all the study areas. Cemeteries of different religion and cultural beliefs demonstrate the history of mining expansion in Perak and this obvious land use can be viewed in Kampar where the Chinese incorporated their cultural and religious beliefs in feng shui selection of hilly areas for the location of their cemeteries. These features characterize the mining history in Kinta that 
evidences the activity of Chinese in Kampar as also in Gopeng with it's Christian cemetery that is linked to the establishment of European companies in Gopeng since the late $19^{\text {th }}$ century.

Supporting infrastructure and ancillary industries, such as timber mills, brickworks, smithies and foundries still exist in the study area. These offer additional evidence and values and can be graded as B and C items of heritage significance under the NSW criteria. These enrich the picturesque-ness of historic mining in Kinta especially in Batu Gajah, Chemor, Gopeng, Kampar, Menglembu and Papan. Aspects of adjunct settlements, established as a consequence of mining to service agriculture and market gardening, can be found widely across the study area. Landscape modifications, due to mining are a major extant cultural landscape component that survives, and these historic landscapes can be observed accross most of the study areas especially in Batu Gajah, Chemor, Papan, Tronoh, Tanjung Tualang, Kampar, Kota Bahru and Malim Nawar. An old map by Tregonning (1963), which tabulates the location of mines in Kinta District in 1960 highlights the location of dredges, Chinese mines, sites that used the gravel pump method and also the location of the European-owned mines. Based on this map, the location of several dredges can be identified alongside Kinta River, and this information supported by the extant mining dredge ponds correlate to areas mapped by Tregonning (1963). The dredge ponds, in contrast to the ponds resulting from open pit mining through the hydraulic or gravel pump method, vary in size and are usually smaller than the dredge ponds. In addition, extant mullock and tailing dumps can be sighted in the study area especially in Batu Gajah, Tanjung Tualang, Kampar, Kota Bahru and Malim Nawar.

\subsection{Justifying heritage values of Kinta Valley former mining landscape}

Preliminary research findings have now been formulated, arising from this doctoral research project, and therefore, it is possible to consider the National Heritage criteria in assessing the heritage significance in Kinta to assess whether each of the sites contain historic values that are able to explain the history, scientific, social and aesthetic values of the sites, areas and landscapes. National Heritage criteria "(a) the historical importance, association with or relationship to Malaysian history", and criteria "(e) the potential to educate, illustrate or provide further scientific investigation" in relation to Malaysian cultural heritage would best describe Kinta Valley as a major mining district in Malaysia. Including social and cultural values and history, the alluvial mining technology achievements and the aesthetic qualities of these landscapes further demonstrates the meritorious significance for conservation recognition of this historic mining landscape. Accordingly, a preliminary conclusion of this research is that the Malaysian National Heritage criteria met demonstrating that Kinta Valley is eligible to be nominated for National Heritage listing.

\subsection{Conclusion}

Since mining crafted a dramatic cultural landscape in Kinta Valley, the protection and conservation of this significant place should be prioritized by the Perak State Government. 
These extant mining features and mining 'relic' places are of state and national significance having regard to the preliminary heritage assessment that has been undertaken and discussed in this paper. In reference to the Perak State Structure Plan 2020, Kinta District has been categorized into the metropolitan district of Kinta Valley, hence recognizing evidence of its economy and physical development expansion, but worrying that former mining land can be used as part of metropolitan development expansion (Department of Town and Regional Planning, 2008). This Structure Plan planning is a threat to the Kinta Valley former mining landscape and therefore it's heritage. Hence, a research conclusion drawn is that this significance of this cultural landscape should be integrated with planning agendas for Kinta District and Kampar District within state and district documents (Perak State Structure Plan 2020; Ipoh Local Plan 2020; and the Kinta Local Plan 2020). Further, former tin mining landscapes in Malaysia are now relatively scarce and irreplaceable and only a conservation program will secure these historical places from being lost forever. Additionally, definitions and the content of the National Heritage Act 2005 should be reviewed to better acknowledge mining places as being part of Malaysia's cultural landscape conservation obligations.

\section{Acknowledgement}

Acknowledgement is given to Mr. Ramli bin Osman, Senior Research Officer from the Department of Minerals and Geosciences of Perak for his kindness and courtesy in providing information relating to ex-mining land in Perak. Hiking to mining dam accompanied by Mr. Ramli was a thrill and an unforgettable memory. A special thanks goes to Tan Sri Dato' Hew See Tong and his son Ir. Hew Fen Yee for their continuous support as well as providing old photographs used in this research. Also to the School of Architecture \& Built Environment at Deakin University for conference fund support together with the Ministry of Education Malaysia (MOE) and UiTM for a PhD scholarship into this topic. This paper forms part of a larger PhD research study, and has Ethics approval from Deakin's Research Ethics Committee (DUHREC) 2014-075.

\section{References}

Ahmad, A.G. (2009). Urban conservation in Malaysia: safeguarding cultural heritage.

Ahmad, S. \& Jones, D. (2013, 24-26 May 2013). The importance and significance of heritage conservation of extin mining landscape in Perak, Malaysia, the Abode of Grace Paper presented at the The Asian Conference on Asian Studies (ACAS), Ramada Osaka, Japan

American Society of Landscape Architects. (n.d). Interview with Franceso Bandarin, Director, UNESCO World Heritage. ASLA News.

http://www.asla.org/ContentDetail.aspx?id=25842

Australia ICOMOS. (n.d). Understanding Cultural Landscapes: Australia ICOMOS. 
Ahmad, S., \& Jones, D. / Asian Journal of Environment-Behaviour Studies (ajE-Bs), 3(10) Sep / Oct 2018 (p.142-151)

Ballinger, R. (2012). Cultural landscapes training manual: a guide for historical societies. Australia: Federation of Australian Historical Societies Inc.

Department of Town and Regional Planning. (2008). Perak State Structure Plan 2020 [Rancangan Struktur Negeri Perak 2020]. Malaysia: Department of State Town and Planning, Perak State.

Dozolme, P. (2013). Mining sites and landscapes on the UNESCO World Heritage List. from http://mining.about.com/od/ClosingReclaimingMine/a/Mining-Sites-And-Landscapes-On-The-Unesco-WorldHeritage-List.htm

Drew, G. (2012). Interpreting South Australia's mining heritage. From http://www.docstoc.com/docs/117453949/Interpreting-South-Australia-Mining-Heritage ; accessed 1 July 2013.

Everitt, W.E. (1952). A history of mining in Perak Federation of Malaya.

Heritage Branch Department of Planning. (2009). Assessing significance for historical archaeological sites and 'relic' NSW, Australia: Heritage Branch Department of Planning.

ICOMOS-TICCIH. (2011). Joint ICOMOS-TICCIH Principles for the conservation of industrial heritage sites, structures, areas and landscapes. 17th ICOMOS General Assembly, Paris: ICOMOS.

Idrus, A., Khamidi, F. \& Sodangi, M. (2010). Maintenance management framework for conservation of heritage buildings in Malaysia. Modern Applied Science, 4(11), 66-77.

Kampar District Council. (2011). Gopeng giant pipes. In R. L. S. Bhd. \& K. D. Council (Eds.). Perak, Malaysia.

Khoo, S.N., \& Lubis, A.R. (2005). Kinta Valley: pioneering Malaysia's modern development: Areca Books.

Lennon, J. (1997). Case study of the cultural landscapes of the Central Victorian goldfields: Department of the Environment.

Minerals and Geoscience Department Malaysia. (2012). Malaysia Mining Industry 2011. Kuala Lumpur: Minerals and Geoscience Department Malaysia.

National Heritage Act 2005, Ministry of Culture, Art and Heritage, Malaysia (2005).

Osman, R.M, \& Ishak, M.A. (2012). Geospatial analysis of ex-mining land of Perak. Paper presented at the National Geoscience Conference, Pullman Hotel, Kuching, Malaysia.

Osman, R.M. (2013). Rate of development of ex-mining land in Peninsular Malaysia. Paper presented at the National Geoscience Conference 2013, Kinta Riverfront Hotel\&Suites, Ipoh, Malaysia.

Pearson, M. \& McGowan, B. (2000). Mining heritage places assessment manual: Canberra : Australian Council of National Trusts : Australian Heritage Commission.

Pearson, M. \& McGowan, B. (2009). Mining sites in NSW : history and heritage Industry and Investment NSW.

Pearson, M. \& Sullivan, S. (1995). Looking after heritage places : the basics of heritage planning for managers, landowners and administrators / Michael Pearson \& Sharon Sullivan: Carlton, Vic. : Melbourne University Press.

Stuart, I. (2012). Identifying the industrial landscapes. In J. Douet (Ed.), Industrial heritage re-tooled: The TICCIH guide to industrial heritage conservation. Lancaster: Carnegie Publishing Ltd.

Taylor, K. (2009). Cultural landscapes and Asia: reconciling international and Southeast Asian regional values. Landscape Research, 34(1), 7-31. 
TICCIH. (2003). The Nizhny Tagil Charter for the industrial heritage. Russia: The International Committee for the Conservation of the Industrial Heritage

The Malaysian Chamber of Mines. (n.a). Save the nation's legacy for the future. The Malaysian Chamber of Mines. Kuala Lumpur, Malaysia.

Tregonning, K. G. (1963). Straits tin : a brief account of the first seventy-five years of the Straits Trading Company, Limited: The Straits Times Press (M) Ltd. Singapore.

UNESCO. (2012). Operational Guidelines for the Implementation of the World Heritage Convention. Paris: UNESCO World Heritage Centre.

www.Malaysia.com. (2013). Tin smelting in Perak. from http://www.malaysia.com/directory/ 